Volume 3 Nomor 2, Agustus 2018, halaman 115-130

\title{
IDENTIFIKASI LEARNING OBSTACLE PADA POKOK BAHASAN SUDUT PUSAT DAN SUDUT KELILING LINGKARAN
}

\section{LEARNING OBSTACLE IDENTIFICATION OF CENTRAL ANGEL AND INSCRIBED ANGLE ON CIRCLE}

\author{
Lusi Siti Aisah ${ }^{1}$, Kusnandi \\ ${ }^{1}$ Universitas Wiralodra, J1. Ir. H. Djuanda KM.3 Singaraja Indramayu 45213, \\ lusi_sitiaisah@yahoo.com \\ ${ }^{2}$ Universitas Pendidikan Indonesia, J1. Dr. Setiabudhi No. 229 Bandung, \\ kusnandiabadi@yahoo.co.id
}

\begin{abstract}
ABSTRAK
Tujuan dari penelitian ini adalah untuk mengidentifikasi learning obstacleatau kesulitan-kesulitan siswa dalam proses penyelesaian permasalahan yang terkait dengan sudut pusat dan sudut keliling dalam lingkaran. Metode penelitian yang digunakan adalah metode kualitatif dengan teknik pengumpulan data yaitu observasi, tanya-jawab, dan dokumentasi. Pengujian instrumen learning obstacle dilakukan kepada siswa yang telah mendapatkan/ mempelajari materi tersebut. Instrumen diujikan kepada siswa kelas VIII di SMP Negeri 6 Cirebon dan juga kepada beberapa orang mahasiswa pendidikan matematika UPI. Hasilnya ditemukan beberapa hambatan-hambatan yang teridentifikasi dalam memahami konsep sudut pusat dan sudut keliling lingkaran, yaitu: 1) Hambatan epistimologi terkait penerapan konsep sudut pusat dan sudut keliling menghadapi busur yang sama. 2) Hambatan epistimologi terkait variasi informasi yang tersedia serta penerapan definisi sudut pusat dan sudut keliling pada soal. 3) Hambatan epistimologi terkait dalam menganalisis soal. 4) Hambatan epistimologi terkait pengaitan dengan konsep yang lain 5) Hambatan epistimologis terkait memunculkan gagasan dalam menjawab soal.
\end{abstract}

Kata Kunci: Learning Obstacle, Sudut Pusat, Sudut Keliling, Lingkaran

\begin{abstract}
The purpose of this study is to identify learning obstacle or student difficulties in the process of solving problems related to the central angle and the inscribed angle of the circle. The research methods is qualitative methods with data collection techniques are observation, question and answer, and documentation. Testing of learning obstacle instrument is done to students who have got / studied the material. The instrument is tested to grade VIII students at SMP Negeri 6 Cirebon and also to some college students of UPI mathematics education. The result found several obstacles identified in understanding the concept of the central angle and the inscribed angle of the circle, 1) Epistimologi Obstacles related the concept of central angle and inscribed angle apply the same arc. 2) Epistimologi Obstacles related to variations of available information. 3) Epistimologi Obstacles related in analyzing questions. 4) Epistimologi Obstacles related to other concepts 5) Epistimologi Obstacles related create ideas for answering questions.
\end{abstract}

Keywords: Learning Obstacle, Central Angle, Inscribed Angle, Circle 
How to Cite: Aisah, L. S., \& Kusnandi. (2018). Identifikasi Learning Obstacle pada Pokok Bahasan Sudut Pusat dan Sudut Keliling Lingkaran. Mathline: Jurnal Matematika dan Pendidikan Matematika, Vol.3, No.2, 115-130.

\section{PENDAHULUAN}

Pendidikan adalah salah satu hal penting yang tidak dapat dipisahkan dari kehidupan manusia. Pendidikan bertujuan untuk mengoptimalkan potensi siswa serta memberi pengalaman belajar sehingga siswa mampu belajar secara sinergi. Pendidikan khususnya pelajaran matematika sering dianggap sebagai pelajaran yang sulit oleh siswa. Berdasarkan fenomena tersebut tentunya guru harus dapat menggeser posisi pelajaran matematika sebagai pelajaran yang sulit menjadi pelajaran yang lebih mudah dimengerti siswa. Dalam keadaan apapun sebenarnya kita semua memiliki potensi. Setiap siswa memiliki potensi yang berbeda-beda. Tidak ada siswa yang bodoh / tidak berpotensi, yang ada hanyalah siswa yang malas. Peran guru yaitu untuk membantu siswa mencapai kemampuan (dalam belajar matematika) secara optimum. Menurut James B. Brow seperti yang dikutip oleh Suryosubroto (2002), mengemukakan bahwa tugas dan peranan guru antara lain: menguasai dan mengembangkan materi pelajaran, merencanakan dan mempersiapkan pelajaran sehari-hari, mengontrol dan mengevaluasi kegiatan siswa. Jadi hal yang paling penting dimiliki guru adalah menguasai materi pelajaran dan mengembangkannya. Setelah itu hal kedua yang tidak kalah pentingnya adalah merencanakan dan mempersiapkan pelajaran sehari-hari, termasuk mempersiapkan bahan ajar yang cocok diterapkan di kelas. Bahan ajar atau materi pembelajaran (instructional materials) secara garis besar terdiri dari pengetahuan, keterampilan, dan sikap yang harus dipelajari siswa dalam rangka mencapai standar kompetensi yang telah ditentukan. Secara terperinci, jenis-jenis materi pembelajaran terdiri dari pengetahuan (fakta, konsep, prinsip, prosedur), keterampilan, dan sikap atau nilai (Gafur, 1986).

Di dalam matematika terdapat cabang-cabang ilmu diantaranya meliputi geometri, aljabar, aritmatika, kalkulus, analisis dan lain-lain. Dalam penulisan ini penulis memilih cabang geometri. Geometri terdiri dari titik-titik, garis-garis dan bidang-bidang. Geometri adalah sebuah subjek abstrak tetapi mudah untuk digambarkan dan mempunyai banyak penerapan praktis yang nyata, Ed (2003). Walaupun geometri mudah untuk digambarkan tetapi pada kenyataannya banyak siswa yang masih merasa kesulitan untuk memahami konsep geometri yang diajarkan. Lingkaran merupakan salah satu bentuk geometri. Lingkaran adalah sebuah bangun yang terdiri atas titik-titik dengan jarak yang sama dari titik pusatnya (Ed, 2003). Unsur-unsur dari sebuah lingkaran diantaranya titik pusat, jari- 
jari, diameter, busur, tali busur, tembereng, juring, dan apotema. Ada beberapa sudut yang berhubungan dengan lingkaran, contohnya yaitu sudut pusat, sudut keliling, sudut di antara dua tali busur lingkaran dsb.

Banyak siswa menganggap materi sudut-sudut pada lingkaran ini merupakan materi yang sulit. Saat pembelajaran materi tersebut, siswa sering hanya di-drill untuk menghafal rumus dan mengerjakan soal-soal yang hampir identik, sehingga jika soal diubah sedikit saja mereka tidak mampu atau mengalami kesulitan dalam menyelesaikannya. Kesulitan seperti ini dikenal dengan hambatan epistimologis.

Menurut Duroux (Suryadi, 2010) hambatan epistimologis merupakan hambatan yang muncul akibat dari pengetahuan seseorang yang terbatas pada konteks tertentu. Jika orang tersebut berhadapan dengan konteks yang berbeda, maka pengetahuan yang dimiliki menjadi tidak dapat digunakan lagi atau dia akan mengalami kesulitan untuk menggunakannya. Hambatan epistimologis terutama sangat terlihat dari ketergantungan siswa pada pengalaman penyelesaian masalah sebelumnya. Jika siswa mengalami hambatan dalam proses belajarnya (learning obstacle) maka hambatan itu dapat menyebabkan siswa mengalami kegagalan atau setidaknya kurang berhasil dalam mencapai tujuan belajar.

Berdasarkan latar belakang yang telah diuraikan di atas maka yang menjadi rumusan masalah dalam penulisan ini adalah, Apa saja kesulitan-kesulitan siswa (learning obstacle) dalam proses penyelesaian permasalahan yang terkait dengan konsep sudut pusat dan sudut keliling lingkaran?Adapun tujuan yang ingin dicapai dari penelitian ini yaitu mengetahui Apa saja kesulitan-kesulitan siswa (learning obstacle) dalam proses penyelesaian permasalahan yang terkait dengan konsep sudut pusat dan sudut keliling lingkaran. Setelah mengidentifikasi learning obstacle pada konsep sudut pusat dan sudut keliling pada lingkaran, para guru diharapkan mampu menyusun bahan ajar yang lebih baik lagi agar siswa dapat mengerti dan menguasai materi dengan baik.

\section{METODE PENELITIAN}

Metode penelitian yang digunakan adalah metode kualitatif. Metode kualitatif ini dipilih agar dapat lebih rinci mengungkapkan gejala atau fenomena yang lebih kompleks dan sulit diungkapkan jika menggunakan metode kuantitatif. Seperti yang diungkapkan oleh Ruseffendi (2005) bahwa penelitian kualitatif itu perlu dilakukan untuk mengungkapkan sesuatu yang oleh penelitian kuantitatif belum terungkapkan. Subjek pada penelitian untuk mengidentifikasi learning obstaclepada konsep sudut pusat dan sudut 
keliling lingkaran yaitu siswa kelas VIII SMP Negeri 6 Cirebon tahun ajaran 2015/2016 sebanyak 35 siswa, dan mahasiswa pendidikan matematika UPI semester I sebanyak 8 orang.

Teknik pengumpulan data dalam penelitian ini dilakukan dengan proses triangulalsi data yaitu melakukan uji instrumen learning obstacle, observasi, dan dokumentasi. Sedangkan analisis data pada penelitian ini dilakukan dengan terlebih dahulu mengumpulkan seluruh data yang diperoleh untuk selanjutnya dilakukan penyeleksian dan pengelompokkan data yang ada kemudian melakukan interpretasi secara naratif.

\section{HASIL DAN PEMBAHASAN}

Instrumen yang digunakan berbentuk tes tertulis sebanyak delapan soal. Analisis hasil pengerjaan instrumen diuraikan berdasarkan indikator kemampuan mengerjakan soal pada tiap nomornya:Berikut diuraikan lebih detail mengenai hambatan epistimologis yang muncul berkaitan hasil pengerjaan siswa terhadap instrumen yang diujikan.

\section{Hambatan epistimologi terkait penerapan konsep sudut pusat dan sudut keliling menghadapi busur yang sama}

Siswa masih terlihat kesulitan dalam menerapkan konsep sudut pusat dan sudut keliling yang menghadapi busur yang sama. Pada dasarnya siswa mengetahui konsepkonsep yang berkaitan dengan sudut pusat dan sudut keliling. Tetapi saat berhadapan dengan soal, siswa menjadi kebingungan. Hal ini terlihat dari jawaban siswa saat menyelesaikan soal.

Beberapa siswa melakukan kekeliruan saat menjawab soal, seperti pada soal no 2 mereka beranggapan bahwa setiap sudut keliling dalam lingkaran adalah sama besar. Siswa melupakan syarat utama yaitu harus menghadap busur yang sama. Beberapa siswa keliru menyatakan besar sudut keliling adalah dua kali sudut pusat.

\section{Soal Nomor 2:}

Berapakah besar $\angle \mathrm{BAC}$ ?

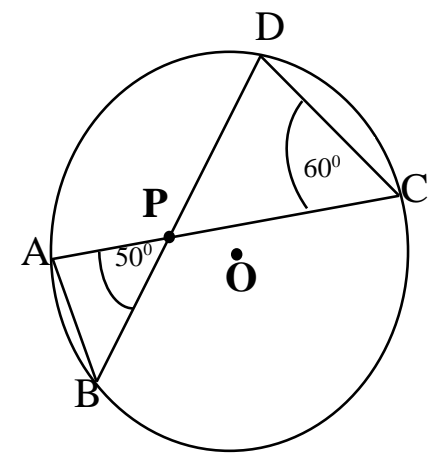


Indikator kemampuan siswa dalam mengerjakan soalnomor 2 ini dapat dilihat pada Tabel 1. berikut:

Tabel 1. Indikator Kemampuan Mengerjakan Soal Nomor 2

\begin{tabular}{|c|c|}
\hline No. & Indikator Kemampuan Mengerjakan Soal dengan Cara 1 \\
\hline 1. & $\begin{array}{c}\text { Menentukan besar } \angle \text { ABD dengan menggunkan konsep sudut keliling menghadapi } \\
\text { busur yang sama }(\overline{A D}) \text {. }\end{array}$ \\
\hline 2. & Menerapkan konsep jumlah sudut dalam $\triangle \mathrm{ABP}$ \\
\hline No. & Indikator Kemampuan Mengerjakan Soal dengan Cara 2 \\
\hline 1. & $\begin{array}{l}\text { Memunculkan gagasan untuk menentukan besar } \angle \mathrm{CPD} \text { dengan menggunakan } \\
\text { konsep sudut bertolak belakang. }\end{array}$ \\
\hline 2. & Menerapkan konsep jumlah sudut dalam segitiga $\triangle \mathrm{CPD}$. \\
\hline 3. & Menerapkan konsep sudut keliling pada busur $\widehat{B C}$ untuk mencari besar $\angle \mathrm{BAC}$. \\
\hline
\end{tabular}

Untuk melihat kemampuan siswa dan mahasiswa dalam mengerjakan soal ini dapat dilihat pada tabel 2 berikut ini dengan total siswa adalah 35 dan total mahasiswa adalah 8 .

Tabel 2. Distribusi Kemampuan Menyelesaikan Soal Nomor 2

\begin{tabular}{cccccc}
\hline $\begin{array}{c}\text { Jenis } \\
\text { Penyelesaian }\end{array}$ & No. & $\begin{array}{c}\text { Banyak } \\
\text { Siswa }\end{array}$ & Persentase & $\begin{array}{c}\text { Banyak } \\
\text { Mahasiswa }\end{array}$ & Persentase \\
\hline Cara 1 & 1. & 24 & $68,57 \%$ & 2 & $25 \%$ \\
& 2. & 23 & $65,71 \%$ & 2 & $25 \%$ \\
Cara 2 & 1. & 0 & $0 \%$ & 6 & $75 \%$ \\
& 2. & 0 & $0 \%$ & 5 & $62,5 \%$ \\
& 3. & 0 & $0 \%$ & 5 & $62,5 \%$ \\
\hline
\end{tabular}

\section{Analisis Learning Obstacle Soal Nomor 2}

Berdasarkan tabel distribusi di atas terlihat bahwa 23 siswa $(65,71 \%)$ telah memiliki kemampuan dalam menerapkan konsep jumlah sudut segitiga dan menentukan besar $\angle \mathrm{ABD}$ dengan menggunakan konsep sudut keliling menghadapi busur yang sama $(\overline{A D})$. Ini berarti 12 siswa yang lain $(34,29 \%)$ masih belum mengusai kemampuan tersebut. Adapun kekeliruan dan kesalahan yang dilakukan oleh siswa yaitu:

1. Mereka beranggapan bahwa setiap sudut keliling dalam lingkaran adalah sama besar.

Siswa menjawab besar $\angle \mathrm{BAC}=$ besar $\angle \mathrm{DCA}$.

2. Menyatakan $\angle \mathrm{BAC}=\angle \mathrm{APB}+\angle \mathrm{DCA}$

Berdasarkan Tabel 2, pada tingkat mahasiswa, sebanyak 7 orang $(87,5 \%)$ mampu mengerjakan soal. Sisanya 1 orang $(12,5 \%)$ melakukan kekeliruan seperti yang dilakukan 
siswa pada no 1 yaitu beranggapan bahwa setiap sudut keliling lingkaran adalah sama besar tanpa mengingat syarat harus menghadap busur yang sama.

Hambatan epistimologi terkait penerapan konsep sudut pusat dan sudut keliling menghadapi busur yang sama juga muncul pada pengerjaan siswa pada soal nomor 1, nomor 3, dan nomor 4. Berikut akan diuraikan secara singkat mengenai analisis learning obstacle-nya.

\section{Soal Nomor 1:}

Perhatikan Gambar di samping ini, dari tiga sudut yaitu $\angle \mathrm{EAD}, \angle \mathrm{EBD}$, dan $\angle \mathrm{ECD}$ sudut manakah yang paling besar? Beri penjelasannya!

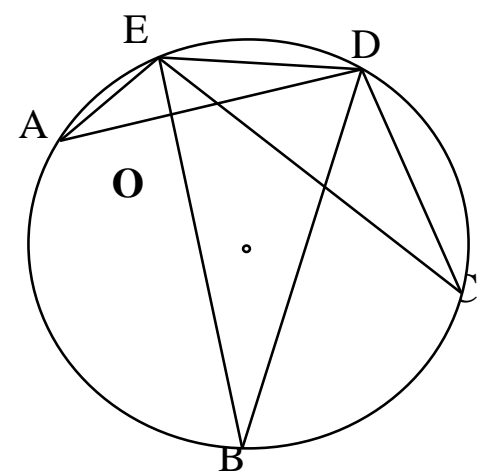

\section{Analisis Learning Obstacle Soal Nomor 1}

Berdasarkan hasil pengerjaan siswa, siswa tidak ada yang menjawab dengan benar. Namun bukan berarti siswa tidak mengetahui konsep sudut keliling lingkaran menghadapi busur yang sama adalah sama besar. Hal ini dapat terlihat dalam proses pengerjaan soalsoal lainnya, dimana siswa mampu menggunakan konsep tersebut dalam menjawab soal. Ketidakmampuan siswa menjawab soal nomor satu ini dapat terjadi karena siswa terjebak pada konteks kalimat yang menanyakan sudut manakah yang paling besar. Siswa mengira pada ketiga sudut itu pasti salah satunya ada yang lebih besar.

Selain itu dari hasil pengerjaan siswa terhadap instrumen yang diberikan, dapat diduga siswa masih bingung dalam menentukan sudut keliling lingkaran. Sedangkan pada tingkat mahasiswa, seluruhnya telah mengetahui konsep sudut keliling lingkaran yang menghadap busur yang sama adalah sama besar. 


\section{Soal Nomor 3}

Besar $\angle \mathrm{ACO}=25^{\circ}$, hitunglah besar $\angle \mathrm{CBO}$ !

A

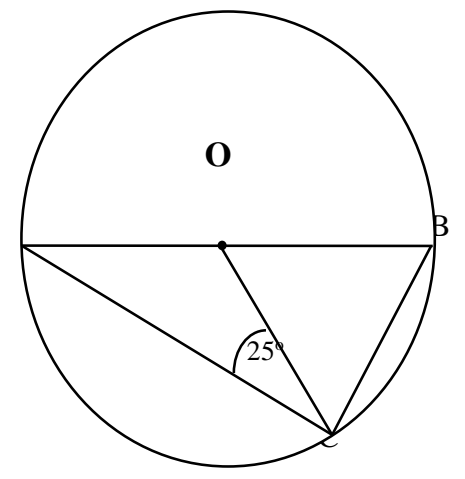

\section{Analisis Learning Obstacle Soal Nomor 3}

Kesulitan yang dihadapi siswa dalam menjawab pertanyaan no 3 yaitu:

1. Sebagian besar siswa tidak mengetahui konsep sudut keliling yang menghadap diameter lingkaran itu besarnya $90^{\circ}$.

2. Siswa tidak menyadari bahwa $\triangle \mathrm{AOC}$ dan $\triangle \mathrm{OCB}$ adalah segitiga samakaki.

\section{Soal Nomor 4}

$\mathrm{KLN}$ adalah segitiga samakaki, besar $\angle \mathrm{KML}=50^{\circ}$ dan besar $\angle \mathrm{OKN}=15^{\circ}$. Hitunglah besar $\angle \mathrm{KNL}$ !

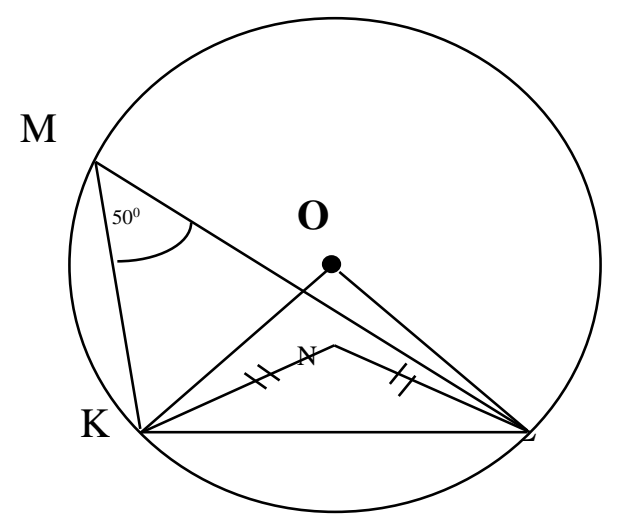

\section{Analisis Learning Obstacle Soal Nomor 4}

Berdasarkan tabel distribusi di atas, banyak siswa yang belum memiliki kemampuan dalam menyelesaikan soal nomor 4. Hanya $22,86 \%$ yang menunjukan bahwa siswa memiliki kemampuan dalam menentukan besar $\angle$ KOL dengan menggunakan konsep sudut pusat dan sudut keliling yang menghadapi busur yang sama. Kesulitan dan kekeliruan siswa dalam menyelesaikan soal nomor 4 yaitu: Siswa mengetahui bahwa besar sudut pusat adalah dua kali besar sudut keliling tetapi banyak siswa keliru menentukan sudut pusat, mereka beranggapan bahwa $\angle \mathrm{KNL}$ adalah sudut pusat yang menghadap busur yang sama dengan sudut keliling $\angle \mathrm{KML}$. 
Beberapa siswa telah menentukan $\angle \mathrm{KOL}$ adalah sudut pusat yang menghadap busur yang sama dengan sudut keliling $\angle$ KML. Namun, setelah itu mereka melakukan kekeliruan dengan menganggap besar $\angle \mathrm{KNL}$ adalah dua kali sudut pusat $\angle \mathrm{KOL}$.

\section{Hambatan epistimologi terkait variasi informasi yang tersedia serta penerapan definisi sudut pusat dan sudut keliling pada soal}

Dalam dalil pengontrasan dan keanekaragaman (contrast and variation theorem) menurut Bruner (Suherman, 2001), dinyatakan bahwa pengontrasan dan keanekaragaman sangat penting dalam melakukan pengubahan konsep dipahami dengan mendalam. Anak perlu diberi contoh yang memenuhi rumusan atau teorema yang diberikan. Selain itu mereka perlu juga diberi contoh-contoh yang tidak memenuhi rumusan, sifat atau teorema, sehingga diharapkan anak tidak mengalami salah pengertian terhadap konsep yang sedang dipelajari. Keanekaragaman juga membantu anak dalam memahami konsep yang disajikan, karena dapat memberikan belajar bermakna bagi anak.

Soal yang berkaitan dengan hambatan jenis ini adalah soal nomor 5. Dalam mengerjakan soal nomor 5, siswa harus menyeleksi informasi yang tersedia pada soal. Tidak semua informasi yang terdapat pada soal nomor 5 digunakan untuk mencari jawaban yang ditanyakan.

Pada soal no 5 diketahui besar tiga buah sudut yang salah satunya adalah sudut keliling menghadapi busur $\overline{Q R}$ dan yang lainnya bukan sudut keliling. Dari hasil pengerjaan siswa pada nomor 5, dapat terlihat siswa bingung dalam menjawab soal. Sebagian siswa keliru menentukan sudut keliling lingkaran yang menghadap $\bar{Q} \bar{R}$. Siswa mengira $\angle$ QTR adalah sudut keliling yang menghadap $\bar{Q} \bar{R}$. Hal ini menunjukkan siswa masih belum paham tentang definisi sudut keliling lingkaran.

\section{Soal Nomor 5}

Perhatikan gambar di samping, jika besar $\angle \mathrm{QPR}=60^{\circ}, \angle \mathrm{QTR}=50^{\circ}$, dan $\angle \mathrm{QSR}=$ $40^{0}$ berapakah besar $\angle \mathrm{OQR}$ ?

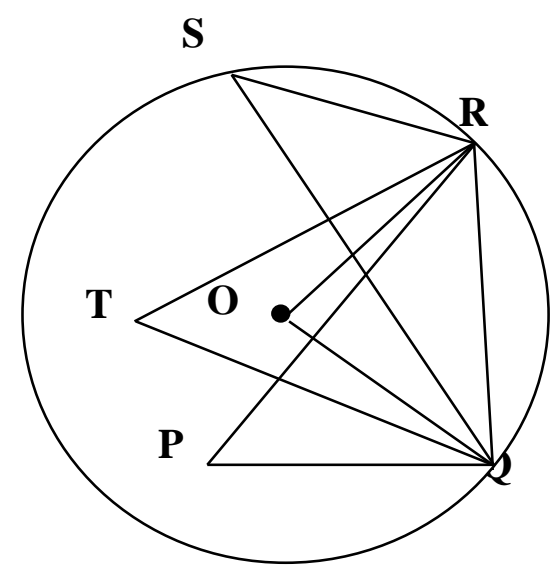


Indikator kemampuan siswa dalam mengerjakan soal ini dapat dilihat pada Tabel 3. berikut:

Tabel 3. Indikator Kemampuan Mengerjakan Soal Nomor 5

\begin{tabular}{cl}
\hline No. & \multicolumn{1}{c}{ Indikator Kemampuan Mengerjakan Soal } \\
\hline 1. & $\begin{array}{l}\text { Menggunakan definisi sudut keliling untuk menentukan sudut keliling yang } \\
\text { menghadap busur } \overline{Q R} .\end{array}$ \\
2. & $\begin{array}{l}\text { Menggunakan konsep besar sudut pusat dan sudut keliling menghadapi busur yang } \\
\text { sama untuk mencari besar } \angle \mathrm{QOR} . \angle \mathrm{QOR}=2 \mathrm{X} \angle \mathrm{QSR}\end{array}$ \\
3. & Mencari $\angle \mathrm{OQR}$ dengan menerapkan konsep jumlah sudut dalam segitiga dan besar \\
& sudut pada segitiga sama kaki $\triangle \mathrm{QOR} .\left(\angle \mathrm{OQR}=\frac{180^{\circ}-\angle \mathrm{QOR}}{2}\right)$ \\
\hline
\end{tabular}

Untuk melihat kemampuan siswa dan mahasiswa dalam mengerjakan soal nomor 5 ini dapat dilihat pada tabel 4 berikut ini:

Tabel 4. Distribusi Kemampuan Menyelesaikan Soal Nomor 5

\begin{tabular}{ccccc}
\hline No & Banyak Siswa & Persentase & Banyak Mahasiswa & Persentase \\
\hline 1. & 2 & $5,71 \%$ & 8 & $100 \%$ \\
2. & 1 & $2,86 \%$ & 8 & $100 \%$ \\
3. & 0 & $0 \%$ & 8 & $100 \%$ \\
\hline
\end{tabular}

Total siswa adalah 35 dan total mahasiswa adalah 8

\section{Analisis Learning Obstacle Soal Nomor 5}

Berdasarkan tabel distribusi di atas, terlihat bahwa pada tingkat mahasiswa, 100\% telah menjawab dengan benar. Sedangkan siswa masi banyak yang menjawab keliru. keliruan dan kesulitan siswa dalam menyelesaikan soal nomor 5 yaitu:

1) Siswa belum mampu menyaring informasi yang ada pada soal.

2) Siswa belum memahami definisi sudut keliling dengan benar, beberapa siswa beranggapan bahwa sudut keliling adalah sudut yang terletak di atas sudut pusat. Seharusnya, sudut keliling adalah sudut yang dibentuk oleh dua buah tali busur yang salah satu ujungnya berimpit.

3) Siswa tidak menyadari bahwa $\triangle \mathrm{OQR}$ adalah segitiga samakaki. Sehingga setelah mengetahui besar sudut pusat $\angle \mathrm{QOR}$ mereka bingung menghitung $\angle \mathrm{OQR}$.

4) Beberapa siswa mengira bahwa $\triangle \mathrm{OQR}$ adalah segitiga samasisi, sehingga mereka menjawab besar $\angle \mathrm{OQR}$ adalah $60^{\circ}$.

\section{Hambatan epistimologi terkait kemampuan menganalisis soal}

Berdasarkan tahap analisis teori Van Hiele (Suherman, 2001), pada tahap ini sudah tampak adanya analisis terhadap konsep dan sifat-sifatnya. Siswa dapat menentukan sifat- 
sifat suatu dengan melakukan pengamatan, pengukuran, eksperimen, menggambar dan membuat model. Siswa mampu mampu menyebutkan keteraturan yang terdapat pada benda geometri itu. Meskipun demikian, siswa belum sepenuhnya dapat menjelaskan hubungan antara sifat-sifat tersebut, belum dapat melihat hubungan antara beberapa geometri dan definisi tidak dapat dipahami oleh siswa.

Hambatan yang terkait kemampuan menganalisis soal ini contohnya dapat ditemukan pada soal nomor 6. Dalam menjawab soal no 6, siswa harus memperhatikan dan menganalisis gambar dengan cermat. Saat membaca soal, harusnya siswa mampu menyatakan bahwa setiap sudut pada segitiga samasisi adalah $60^{\circ}$ tetapi kenyataannya sedikit sekali siswa yang mampu menayatakannya. Setelah itu siswa harus menganalisis. Dengan melihat pengerjaan siswa dalam mengerjakan soal lainnya dapat dikatakan tingkat kemampuan siswa dalam menganalisi masih rendah.

\section{Soal Nomor 6}

Jika $\mathrm{ABC}$ adalah sebuah segitiga samasisi dan besar $\angle \mathrm{OEA}=25^{\circ}$, tentukan berapakah besar $\angle \mathrm{DEC}$ ?

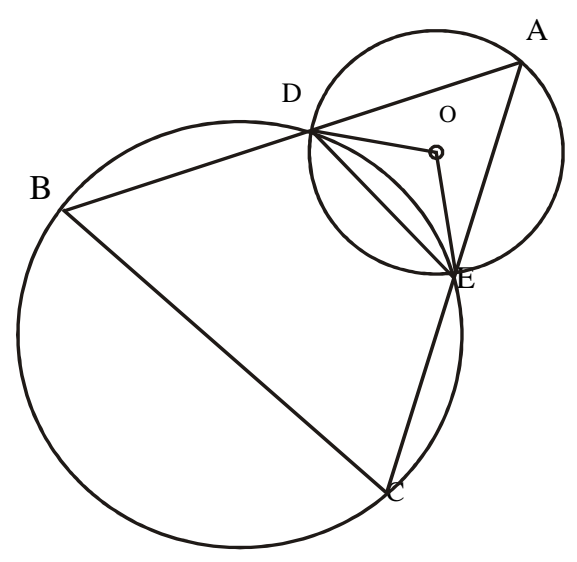

Indikator kemampuan siswa dalam mengerjakan soal ini dapat dilihat pada tabel 5 berikut:

Tabel 5. Indikator Kemampuan Mengerjakan Soal Nomor 6

\begin{tabular}{ll}
\hline No & \multicolumn{1}{c}{ Indikator Kemampuan Mengerjakan Soal } \\
\hline 1. & $\begin{array}{l}\text { Menggunakan konsep besar sudut pada segitiga samasisi } \mathrm{ABC} \text { untuk } \\
\text { menyatakan } \angle \mathrm{A}=60^{\circ} .\end{array}$ \\
2. & $\begin{array}{l}\text { Memunculkan gagasan untuk mencari } \angle \mathrm{DOE} \text { menggunakan konsep besar } \\
\text { sudut pusat dan sudut keliling menghadapi busur yang sama. } \angle \mathrm{DOE}=2 \mathrm{x}\end{array}$ \\
& $\angle \mathrm{DAE}$ \\
& $\begin{array}{l}\text { Mencari } \angle \mathrm{DEO} \text { dengan menggunakan konsep jumlah sudut dalam } \\
\text { segitiga dan besar sudut pada segitiga sama kaki } \triangle \mathrm{DOE} .\end{array}$ \\
& $\left(\angle \mathrm{DEO}=\frac{180^{\circ}-\angle \mathrm{DOE}}{2}\right)$ \\
& \\
& \\
Menggunakan konsep berpelurus untuk mencari $\angle \mathrm{DEC}$, \\
\end{tabular}


Untuk melihat kemampuan siswa dan mahasiswa dalam mengerjakan soal nomor 6 ini dapat dilihat pada tabel 6 berikut ini:

Tabel 6. Distribusi Kemampuan Menyelesaikan Soal Nomor 6

\begin{tabular}{ccccc}
\hline No & Banyak Siswa & Persentase & Banyak Mahasiswa & Persentase \\
\hline 1. & 3 & $8,57 \%$ & 8 & $100 \%$ \\
2. & 1 & $2,86 \%$ & 7 & $87,5 \%$ \\
3. & 1 & $2,86 \%$ & 6 & $75 \%$ \\
4. & 1 & $2,86 \%$ & 6 & $75 \%$ \\
\hline
\end{tabular}

Total siswa adalah 35 dan total mahasiswa adalah 8

\section{Analisis Learning Obstacle Soal Nomor 6}

Berdasarkan distribusi di atas, sebagian besar siswa kesulitan dalam menjawab pertanyaan nomor 6. Kesulitan dan kekeliruan yang dihadapi siswa dalam menjawab pertanyaan no 6 yaitu:

1. Siswa belum mampu menyerap informasi yang tersedia pada soal (siswa belum menyatakan $\angle \mathrm{A}=60^{\circ}$ ).

2. Siswa belum mampu memunculkan gagasan mencari besar $\angle \mathrm{DOE}$.

3. Siswa telah mengetahui bahwa untuk menyelesaikan soal menggunakan sudut berpelurus $\left(\angle \mathrm{DEC}=180^{\circ}-(\angle \mathrm{DEO}+\angle \mathrm{OEA})\right)$. Tetapi mereka keliru menafsirkan bahwa $\angle \mathrm{DEO}$ memiliki besar yang sama dengan $\angle \mathrm{OEA}$.

Pada tingkat mahasiswa, sebanyak $12,5 \%$ belum memunculkan gagasan untuk mencari besar $\angle \mathrm{DOE}$ dan sebanyak $25 \%$ melakukan kesalahan dengan menyatakan bahwa $\triangle \mathrm{ADE}$ adalah segitiga samasisi.

\section{Hambatan epistimologi terkait koneksi dengan konsep yang lain.}

Menurut dalil Pengaitan teori Bruner, Suatu topik akan menjadi sulit dipahami oleh siswa manakala belum menguasai materi prasyarat yang dibutuhkan. Siswa harus diberikan kesempatan sebanyak-banyaknya dalam melihat atau mengkaji kaitan antara suatu topik dengan topik lain atau satu konsep dengan konsep lain yang dipelajari. Dalil pengaitan yang dikemukakan oleh Bruner (Suherman, 2001), erat kaitannya dengan apa yang disebut mathematical connection dalam curriculum and evaluation standard for school mathematics. Ditekankan kepada siswa agar mampu mengkaji dan menerapkan kaitan antara topik-topik matematika dan aplikasinya.

Hambatan yang terkait koneksi dengan konsep yang lain ini contohnya dapat ditemukan pada soal nomor 8 . Soal nomor 8 ini diselesaikan dengan mengaitkan antara 
126 Identifikasi Learning Obstacle pada Pokok Bahasan Sudut Pusat dan Sudut Keliling Lingkaran

konsep sudut sehadap dan berpelurus. Berdasarkan jawaban siswa, sebagian besar belum dapat mengaitkan konsep sudut sehadap pada dua garis sejajar yang dimiringkan untuk mencari sudut keliling.

\section{Soal Nomor 8}

Diketahui JF // IG dan EI // FH,

besar $\angle \mathrm{HLG}=100^{\circ}$. Hitunglah besar $\angle \mathrm{EOG}$ !

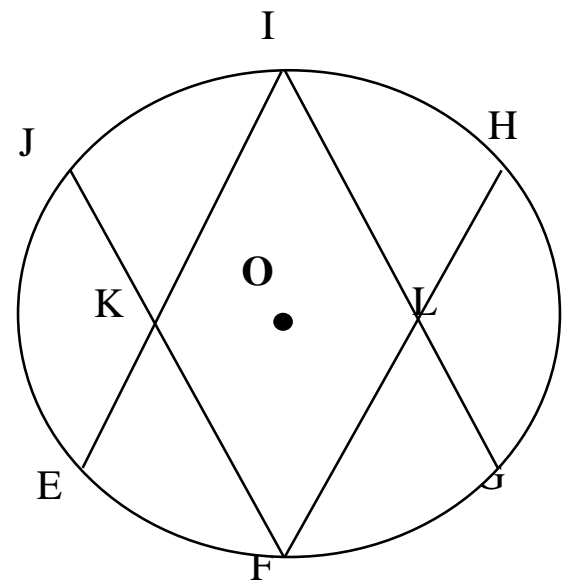

Indikator kemampuan siswa dalam mengerjakan soal ini dapat dilihat pada Tabel 7. berikut:

Tabel 7. Indikator Kemampuan Mengerjakan Soal Nomor 8

\begin{tabular}{ll}
\hline \multicolumn{1}{c}{ No. } & \multicolumn{1}{c}{ Indikator Kemampuan Mengerjakan Soal } \\
\hline 1. & $\begin{array}{l}\text { Memunculkan gagasan untuk mencari sudut keliling } \angle \text { EIG dengan } \\
\text { menggunakan konsep sudut sehadap }(\angle \mathrm{EIG}=\angle \mathrm{FLG}) .\end{array}$ \\
2. & Menentukan besar $\angle \mathrm{FLG}$ dengan konsep sudut berpelurus. \\
3. & $\begin{array}{l}\text { Menggunakan konsep besar sudut pusat } \angle \mathrm{EOG} \text { adalah dua kali sudut keliling } \\
\end{array}$ \\
\hline
\end{tabular}

Untuk melihat kemampuan siswa dan mahasiswa dalam mengerjakan soal nomor 8 ini dapat dilihat pada tabel 8berikut ini:

Tabel 8. Distribusi Kemampuan Menyelesaikan Soal Nomor 8

\begin{tabular}{ccccc}
\hline No & Banyak Siswa & Persentase & Banyak Mahasiswa & Persentase \\
\hline 1. & 1 & $2,86 \%$ & 8 & $100 \%$ \\
2. & 3 & $8,57 \%$ & 8 & $100 \%$ \\
3. & 1 & $2,86 \%$ & 8 & $100 \%$ \\
\hline
\end{tabular}

Total siswa adalah 35 dan total mahasiswa adalah 8 


\section{Analisis Learning Obstacle Soal Nomor 8}

Berdasarkan distribusi di atas, dalam menyelesaikan soal ini sedikit sekali siswa yang sudah memiliki Kesulitan dan kekeliruan yang dihadapi siswa dalam menjawab pertanyaan no 8 yaitu:

1. Siswa belum menerapkan konsep sudut-sudut sehadap pada dua garis sejajar, sehingga mereka tidak mampu menyimpulkan bahwa $\angle$ FLG dan $\angle$ EIG adalah sama besar.

2. Siswa keliru menyatakan $\angle \mathrm{HLG}$ adalah sudut keliling, sehingga mereka menjawab besar $\angle \mathrm{EOG}=2 \times \angle \mathrm{HLG}$.

Pada tingkat mahasiswa, dapat terlihat berdasarkan tabel bahwa 100\% telah menguasai kemampuan yang ada dalam indikator mengerjakan soal nomor

\section{Hambatan epistimologi terkait memunculkan gagasan dalam menjawab soal}

Hambatan yang terkait kemampuan memunculkan gagasan dalam menjawab soal dapat ditemmukan pada soal no 7. Soal no 7 dapat diselesaikan oleh tiga cara, tergantung dari kemampuan siswa dalam memunculkan gagasan dalam menyelesaikannya. Tidak hanya pada soal no 7, pada soal-soal lainnya juga kemampuan memunculkan gagasan sangat penting. Dan dari jawaban siswa dapat diketahui bahwa kemampuan memunculkan gagasan untuk mencari penyelesaian soal masih kurang.

\section{Soal Nomor 7}

Jika besar $\angle \mathrm{ABE}=35^{\circ}$, berapakah besar $\angle \mathrm{BOC}$ ?

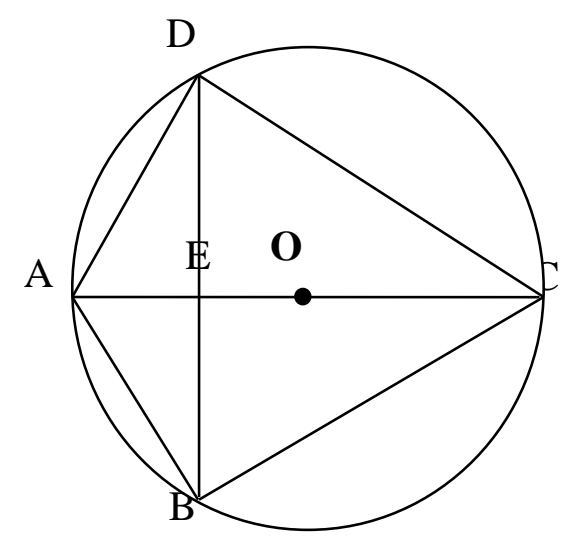

Indikator kemampuan siswa dalam mengerjakan soal ini dapat dilihat pada Tabel 9. berikut: 
Tabel 9. Indikator Kemampuan Mengerjakan Soal Nomor 7

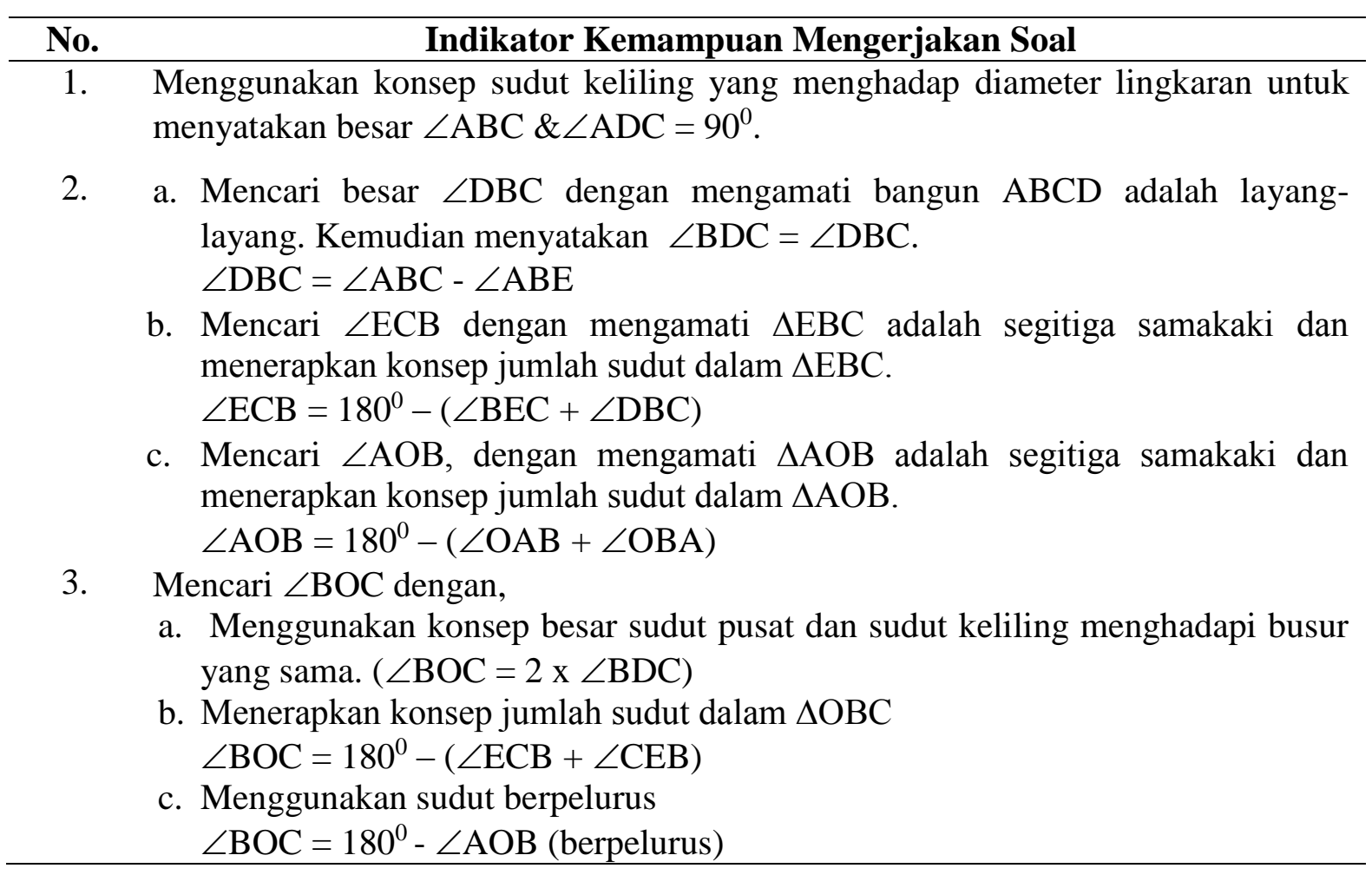

Untuk melihat kemampuan siswa dan mahasiswa dalam mengerjakan soal nomor 7 ini dapat dilihat pada tabel 10 berikut ini:

Tabel 10. Distribusi Kemampuan Menyelesaikan Soal Nomor 7

\begin{tabular}{ccccc}
\hline No. & $\begin{array}{c}\text { Banyak } \\
\text { Siswa }\end{array}$ & Persentase & $\begin{array}{c}\text { Banyak } \\
\text { Mahasiswa }\end{array}$ & Persentase \\
\hline 1. & 10 & $28,57 \%$ & 3 & $37,5 \%$ \\
\hline 2a. & 10 & $28,57 \%$ & 1 & $12,5 \%$ \\
2b. & 0 & $0 \%$ & 3 & $37,5 \%$ \\
2c. & 0 & $0 \%$ & 2 & $25 \%$ \\
3a. & 0 & $0 \%$ & 1 & $12,5 \%$ \\
3b. & 0 & $0 \%$ & 3 & $37,5 \%$ \\
3c. & 0 & $0 \%$ & 2 & $25 \%$ \\
\hline
\end{tabular}

Total siswa adalah 35 dan total mahasiswa adalah 8

\section{Analisis Learning ObstacleSoal Nomor 7}

Berdasarkan distribusi di atas, terlihat bahwa dalam menyelesaikan soal ini baru $28,57 \%$ siswa yang menggunakan sifat sudut keliling yang menghadap diameter lingkaran kemudian mencari besar $\angle$ BDC. Setelah itu siswa bingung menentukan besar $\angle B O C$. Adapun kesulitan dan kekeliruan yang dihadapi siswa dalam menjawab pertanyaan no 7 yaitu: 
1. Sebagian besar siswa tidak menerapkan sifat sudut keliling yang menghadap diameter lingkaran.

2. Siswa belum memiliki kemampuan untuk menyimpulkan $\triangle \mathrm{CDE}$ dan $\triangle \mathrm{CBE}$ kongruen dengan mengamati bangun ABCD adalah layang-layang.

\section{KESIMPULAN}

Berdasarkan hasil analisis terhadap hasil uji instrumen yang telah dilakukan, diperoleh beberapa hambatan-hambatan yang teridentifikasi dalam memahami konsep sudut pusat dan sudut keliling lingkaran, yaitu:

1. Hambatan epistimologi terkait penerapan konsep sudut pusat dan sudut keliling menghadapi busur yang sama.

2. Hambatan epistimologi terkait variasi informasi yang tersedia serta penerapan definisi sudut pusat dan sudut keliling pada soal.

3. Hambatan epistimologi terkait dalam menganalisis soal.

4. Hambatan epistimologi terkait pengaitan dengan konsep yang lain.

5. Hambatan epistimologis terkait memunculkan gagasan dalam menjawab soal.

Berdasarkan hasil identifikasi yang telah penulis lakukan pada konsep sudut pusat dan sudut keliling, saran yang akan diajukan yaitu:

1. Guru perlu memberikan soal-soal yang berkaitan dengan menentukan sudut keliling lingkaran yang menghadapi busur yang sama dengan sudut pusatnya dengan menggunakan dalil pengontrasan dan keanekaragaman Bruner.

2. Guru perlu memberikan soal-soal yang berkaitan dengan menentukan sudut pusat lingkaran yang menghadapi busur yang sama dengan sudut kelilingnya dengan menggunakan dalil pengontrasan dan keanekaragaman Bruner.

3. Dalam memperkenalkan sifat-sifat yang terdapat pada sudut pusat dan sudut keliling lingkaran, sebaiknya guru tidak langsung memberikan begitu saja kepada siswa. Alangkah lebih baiknya dalam menemukan sifat-sifat yang terdapat pada konsep sudut pusat dan sudut kelilng lingkaran itu siswa dapat menemukannya sendiri dengan dibimbing oleh guru.

4. Memberikan soal-soal yang bervariasi dan mengaitkan pada konsep lain untuk melatih kemampuan siswa dalam menyelesaikan soal. 
130 Identifikasi Learning Obstacle pada Pokok Bahasan Sudut Pusat dan Sudut Keliling Lingkaran

\section{DAFTAR PUSTAKA}

Ed, K. (2003). Seri Matematika Keterampilan Geometri. Bandung: Pakar Raya.

Gafur, A. (1986). Desain Instruksional Langkah Sistematis Penyusunan Pola Dasar Kegiatan Belajar Mengajar. Salatiga: Serangkai.

Ruseffendi. (2005). Dasar-Dasar Penelitian Pendidikan dan Bidang Non-Eksata Lainnya. Bandung: Tarsito.

Suherman, E. (2001). Strategi Pembelajaran Matematika Kontemporer. Bandung: JICA UPI.

Suryadi, D. (2010). Didactical Design Research (DDR) dalam Pengembangan Pembelajaran Matematika. Semnas MIPA 2010. Bandung: tidak diterbitkan.

Suryosubroto. (2002). Proses Belajar Mengajar Di Sekolah. Jakarta: Rineka Cipta. 